\title{
Deteksi Gen Ketahanan Terhadap Powdery Mildew Pada Melon (Cucumis melo L. 'Aramis')
}

\author{
BUDI SETIADI DARYONO ${ }^{1}$, HANI CHRISTIN YEMBISE ${ }^{2}$ \\ ${ }^{1}$ Laboratorium Genetika dan Pemuliaan, Fakultas Biologi, Universitas Gadjah Mada \\ J1. Teknika Selatan, Sekip Utara, Sleman, Yogyakarta. 55281 \\ Email: bs_daryono@yahoo.com; hanichristin@gmail.com
}

Received 7 June 2018; Received in revised form 14 July 2018;

Accepted 1 August 2018; Available online 26 November 2018

\begin{abstract}
Melon (Cucumis melo L.) usually used as a fresh fruit, which contained high vitamin C and in Indonesia melon is one of the favorite fruit. Indonesia is a country that has a high biodiversity. One of the potential strategies in order to improve productivity and quality of crops competitiveness is through plant breeding. This study used melon Aramis from PT East West Seed Indonesia hybrid melon from crosses between 7319 (F) with 7347 (M). The research aims to determine the phenotype character of melon cultivar Aramis and to detect powdery mildew resistance gene. The research is conducted in Pusat Inovasi Agro Teknologi (PIAT UGM) Yogyakarta and at the Laboratory of Genetics and Breeding Faculty of Biology, Universitas Gadjah Mada. Resistance genes detection is conducted by Sequence Characterized Amplified Regions method (SCARs) using PCR and showed negative result of Aramis cultivar on detection of gene resistance to powdery mildew.
\end{abstract}

Keywords: Aramis, melon, powdery mildew, SCARs

\section{INTISARI}

Melon (Cucumis melo L.) dimanfaatkan sebagai makanan buah segar yang mengandung vitamin C tinggi dan di Indonesia buah melon digemari oleh masyarakat. Indonesia merupakan negara dengan keanekaragaman hayati yang tinggi, salah satu strategi yang sangat potensial dalam rangka meningkatkan produktivitas, kualitas serta daya saing komoditas tanaman adalah melalui pemuliaan tanaman. Pada penelitian ini digunakan melon hibrida Aramis produksi PT. East West Seed Indonesia hasil persilangan antara tetua betina 7319 (F) dan tetua jantan 7347 (M). Tujuan penelitian ini adalah untuk mengetahui karakter fenotip melon kultivar Aramis serta mendeteksi gen ketahanan terhadap powdery mildew. Penelitian dilaksanakan di Pusat Inovasi Agro Teknologi (PIAT UGM) Yogyakarta serta di Laboratorium Genetika dan Pemuliaan Fakultas Biologi Universitas Gadjah Mada. Hasil daun kemudian dipindahkan ke Laboratorium Genetika dan Pemuliaan Fakultas Biologi UGM untuk dilakukan pengambilan data deteksi gen ketahanan yang dilakukan dengan menggunakan Sequence Characterized Amplified Regions (SCARs). Hasil PCR untuk deteksi gen ketahanan terhadap powdery mildew menunjukan hasil negatif pada melon Aramis sehingga melon Aramis tidak tahan terhadap powdery mildew.

Kata Kunci: Aramis, melon, powdery mildew, SCARs

\section{PENDAHULUAN}

Produksi buah melon di Indonesia terus mengalami peningkatan, berdasarkan data statistik produksi hortikultura yang dikeluarkan oleh kementrian pertanian menunjukkan hasil produksi melon di Indonesia per tahun 2009 sebanyak 85,861 ton, sebanyak 85,161 ton pada tahun 2010, sebanyak 103,840 ton pada tahun 2011, sebanyak 125,447 ton pada tahun 2012, sebanyak 125,207 ton pada tahun 2013 dan mencapai 150,347 per tahun 2014 (Kementerian Pertanian, 2015).
Indonesia merupakan negara yang mempunyai keanekaragaman hayati yang tinggi, salah satu strategi yang sangat potensial dalam rangka meningkatkan produktivitas, kualitas serta daya saing komoditas tanaman adalah melalui pendekatan pemuliaan tanaman yang diharapkan dapat dihasilkan beragam kultivar unggul baru yang selain memiliki produktivitas yang tinggi juga memiliki beberapa karakter lain yang mendukung upaya peningkatan kualitas daya saing seperti ketahanan terhadap penyakit. Salah satu penyakit yang sering menginfeksi tanaman melon di Indonesia adalah powdery mildew 
yang berpengaruh pada penurunan mutu hasil karena menurunkan kandungan gula pada buah, mengurangi aroma hingga bentuk buah yang berubah karena kurangnya daun yang melindungi (Daryono dan Qurrohman, 2009). Tacapa GB dan Tacapa Silver merupakan melon hasil pengembangan dari Laboratorium Genetika dan Pemuliaan Fakultas Biologi Universitas Gadjah Mada dan merupakan hasil persilangan antara PI 371795 dengan Act3 434 dengan testcross Act3 434 untuk Tacapa GB dan hasil persilangan antara PI 371795 dengan Act4 434 dengan testcross Act4 434 untuk Tacapa Silver. Penelitian sebelumnya menunjukkan PI 371795 memiliki gen ketahanan terhadap powdery mildew (Fatmawati and Daryono, 2016; Listiawan, 2009) yang dapat diturunkan pada melon Tacapa sebagai control positif.

Powdery mildew merupakan penyakit dengan penyebaran paling luas yang menginfeksi tanaman Cucurbitaceae termasuk melon. Penyakit ini dapat disebabkan oleh dua patogen Podosphaera xanthii (Castagne) U. Braun \& N. Shishkoff dan Golovinomyces cichoracearum V. P Heluta. P. xanthii merupakan spesies yang paling umum menyebabkan penyakit ini (Lebeda and Mieslerová, 2011; Pérez-García et al., 2009). Daun muda pada Cucurbitaceae lebih tahan terhadap infeksi powdery mildew dibanding daun yang berumur lebih tua sehingga gejala ini biasanya pertama kali muncul pada daun dewasa yang berada dekat pangkal batang dan ternaungi daun lain (Abood and Lösel, 2003; Atak, 2017). Penyakit powdery mildew yang ringan dapat berdampak dalam penurunan mutu hasil, karena mengurangi kandungan gula buah, mengurangi aroma dan merusak tampilan buah (Gadoury et al., 2001; Stummer et al., 2005), tetapi belum terdapat pengalaman dalam pengendalian jamur tepung di Indonesia. Petani umumnya mengendalikan jamur tepung dengan mencabut dan memendam tanaman yang sakit keras atau menggunakan fungisida. Penggunaan fungisida sukar dilakukan karena dapat menyebabkan naiknya biaya produksi, sehingga dibutuhkan informasi mengenai keberadaan gen ketahanan penyakit powdery mildew.

Ketahanan terhadap hama dan penyakit termasuk faktor utama dalam menghasilkan produk maksimum. Melon hibrida kultivar Aramis hasil produksi PT East West Seed Indonesia merupakan hasil persilangan antara tetua betina 7319 dengan tetua jantan 7347 . Keunggulan melon varietas ini memiliki kulit buah yang keras, daya simpan yang lama serta jaring buah yang tebal dan rapat. Melon Aramis mampu beradaptasi dengan baik di dataran rendah dengan ketinggian 50-200 mdpl. Sehingga diperlukan uji deteksi gen pada melon Aramis untuk memberikan informasi keberadaan gen ketahanan terhadap powdery mildew.

\section{METODE}

Penelitian ini dilakukan di greenhouse dan Blok 1 PIAT (Pusat Inovasi Agro Teknologi) Yogyakarta dan Laboratorium Genetika dan Pemuliaan Fakultas Biologi UGM. Penanaman melon dilakukan di greenhouse dan Blok 1, sedangkan dan deteksi gen ketahanan terhadap powdery mildew dilakukan di Laboratorium Genetika dan Pemuliaan.

Persiapan dan Penanaman. Benih melon Aramis, Action 434, Tacapa GB dan Tacapa Silver pertama direndam dengan air hangat yang telah dilarutkan fungisida klorotalonil 2g/l selama 2-4 jam dan kemudian diinkubasi pada ruangan tanpa cahaya selama semalam untuk disemai setelahnya. Benih kemudian disemai di polybag 7 x $5 \mathrm{~cm}$ berisi tanah dan pupuk kandang dengan perbandingan 1:1, NPK $50 \mathrm{~g}$ dan sedikit insektisida. Untuk pertumbuhan vegetatif dipicu dengan diberikan pupuk daun $2 \mathrm{~g} / \mathrm{l}$ dengan kandungan unsur nitrogen yang tinggi. Bibit melon kemudian dapat dipindahkan ke lapangan setelah berumur 10-12 hari atau setelah mempunyai 2-3 helai daun sejati.

Ekstraksi DNA. Ekstraksi dilakukan dengan menggunakan sampel yang berasal dari daun ketiga, keempat dan kelima kultivar dihitung dari pucuk tanaman melon. Daun yang digunakan sebagai sampel diambil dari lahan kemudian disimpan di dalam ice box berisi es untuk dipindahkan dari lahan ke 
laboratorium Genetika dan Pemuliaan Fakultas Biologi UGM, sampel yang telah sampai di laboratorium kemudian dimasukkan ke dalam freezer dengan suhu $-20^{\circ} \mathrm{C}$. Proses ekstraksi dilakukan dengan mengambil sampel daun sebanyak 0,4 gram dari freezer, digerus dengan mortar yang sebelumnya didinginkan dalam lemari pendingin. Reagen Phytopure I ditambahkan ke dalam mortar secara perlahan dan terus digerus sampai daun hancur dan menjadi lembut.

Campuran sampel daun dan reagen tadi dimasukkan ke dalam tube $1,5 \mathrm{ml}$ dan ditambahkan reagen Phytopure II $100 \mu \mathrm{l}$, dikocok perlahan dan diinkubasi pada suhu $65^{\circ} \mathrm{C} 15$ menit kemudian disimpan ke dalam lemari pendingin 20 menit. Setelah 20 menit, sampel ditambahkan $400 \mu 1$ kloroform dingin lalu dikocok perlahan dan ditambahkan $30 \mu 1$ resin Phytopure yang diteteskan secara tegak lurus terhadap tube. Campuran sampel kemudian disentrifugasi 5 menit kecepatan 3000 rpm, supernatan yang terbentuk dipindahkan ke tube 1,5 ml dan ditambahkan isopropanol dingin lewat dinding tube dengan jumlah volume yang sama sesuai volume supernatant lalu dikocok, didiamkan selama 5 menit kemudian disentrifugasi dengan kecepatan 10000 rpm 10 menit. Supernatan akan membentuk pellet DNA berwarna putih di dasar tube. Supernatan dibuang, pelet di dasar tube kemudian dicuci dengan etanol $70 \%$ $100 \mu \mathrm{l}$ kemudian disentrifugasi dengan kecepatan 10000 rpm selama 5 menit. Tahap pencucian pelet ini diulang sebanyak 3 kali. Pada pengulangan terakhir etanol dibuang, pelet dikeringanginkan dan ditambahkan $50 \mu 1$ IXTE buffer untuk memperoleh ekstrak DNA. Hasil ekstraksi kemudian disimpan pada suhu $-20^{\circ} \mathrm{C}$ untuk kemudian dianalisis secara kuantitatif dan kualitatif.

Pengukuran konsentrasi DNA. Ekstrak DNA yang telah dihasilkan kemudian diukur konsentrasinya untuk mengetahui estimasi jumlah DNA total. Pengukuran konsentrasi ini menggunakan spektrofotometer UV-VIS. Pertama, disiapkan spektrofotometer dengan diatur untuk pengukuran absorbansi $260 \mathrm{~nm}$. Spektrofotometer kemudian dikalibrasi dengan menggunakan akuabides, kalibrasi dilakukan dengan tombol auto zero pada alat sampai angka dimonitor menunjukkan angka 0 . Ketika muncul angka 0 akuabides lalu diganti dengan ekstrak DNA yang telah diencerkan dan diukur absorbansinya dengan panjang gelombang 260nm. Angka hasil absorbansi dicatat dan pengukuran diulangi lagi dengan panjang gelombang $280 \mathrm{~nm}$.

Amplifikasi DNA. Amplifikasi DNA dilakukan dengan metode PCR menggunakan primer SCARs. Komponen reaksi yang digunakan dikondisikan dingin pada tempat berisi es. Pertama, dibuat campuran larutan PCR dengan total $25 \mu \mathrm{l}$ berisi faststart 12,5 $\mu \mathrm{l}$, forward primer $2,5 \mu 1$, reverse primer $2,5 \mu 1$, sampel DNA $1 \mu \mathrm{l}$, dan akuabides $6,5 \mu \mathrm{l}$ kemudian dicampur secara hati-hati hingga merata. Mesin PCR diatur dengan formula sebagai berikut: predenaturasi $95^{\circ} \mathrm{C}$ selama 5 menit, denaturasi $95^{\circ} \mathrm{C}$ selama 1 menit, annealing $56^{\circ} \mathrm{C}$ selama 1 menit, extension $72^{\circ} \mathrm{C}$ selama 2 menit dan post extension $72^{\circ} \mathrm{C}$ selama 10 menit. Proses ini dilakukan dengan pengulangan sebanyak 29 kali. Setelah proses selesai, produk PCR disimpan pada suhu $-20^{\circ} \mathrm{C}$ dan siap untuk proses elektroforesis.

Elektroforesis. Elektroforator diisi IXTBE hingga gel agarose terendam. $5 \mu$ l produk dimasukkan pada sumuran berisi marker pada sumuran pertama dan sumuran berikutnya diisi dengan sampel. Alat elektroforesis kemudian ditutup dan dihubungkan ke sumber listrik. Power supply diatur pada $50 \mathrm{~V}$ selama 60 menit lalu ditekan tombol ON. Setelah 60 menit alat lalu dimatikan dan gel dikeluarkan secara hati-hati untuk kemudian diamati dibawah UV transilluminator. Pita DNA yang nampak berpendar didokumentasikan dengan kamera untuk dianalisis lebih lanjut.

Analisis Data. Data kuantitatif dianalisis menggunakan analisa sidik ragam uji $\mathrm{F}$. Apabila pada taraf 5\% diperoleh nilai $\mathrm{F}$ hitung lebih besar dari $F$ tabel maka karakter kuantitatif tersebut akan diuji lanjut dengan menggunakan Uji Beda Nyata Jujur (BNJ). Penghitungan dilakukan dengan menggunakan software PKBT STAT dan data kualitatif disajikan dalam bentuk tabel. Untuk deteksi gen ketahanan terhadap powdery mildew 
dilakukan menggunakan penanda SCAR dengan metode PCR. Keberadaan gen ketahanan terhadap powdery mildew ditandai dengan munculnya band 1058 bp pada gel elektroforesis saat diamati di bawah UV transilluminator.

\section{HASIL}

Uji kuantitatif dan kualitatif dilakukan untuk mengetahui konsentrasi, kemurnian dan keberadaan DNA sampel hasil ekstraksi. Uji kuantitatif dilakukan dengan menggunakan metode spektrofotometri, konsentrasi diketahui berdasarkan kemampuan absorbansi sampel dan kemurnian sampel diketahui berdasarkan rasio absorbansi sampel pada panjang gelombang $260 \mathrm{~nm}$ terhadap nilai absorbansi panjang gelombang $280 \mathrm{~nm}$. Uji kualitatif dilakukan dengan metode elektroforesis.

Tabel 1. Rasio kemurnian DNA dari sampel daun pada beberapa kultivar

\begin{tabular}{cc}
\hline Kultivar & Rasio Kemurnian DNA \\
\hline Tacapa GB & 1,803 \\
\hline Tacapa Silver & 1,941 \\
\hline Action & 1,832 \\
\hline Aramis & 1,648 \\
\hline
\end{tabular}

Hasil Rasio DNA sampel tertinggi dimiliki oleh sampel Tacapa Silver sebesar 1,941 sedangkan rasio terendah dimiliki sampel Aramis yaitu 1,648, sampel Tacapa GB memiliki rasio 1,803 dan Action 434 dengan rasio 1,832 .

Tabel 2. Konsentrasi DNA dari sampel daun pada beberapa kultivar

\begin{tabular}{cc}
\hline Kultivar & Konsentrasi DNA $(\boldsymbol{\mu g} / \mathbf{m l})$ \\
\hline Tacapa GB & 1623 \\
\hline Tacapa Silver & 1898 \\
\hline Action & 655 \\
\hline Aramis & 738 \\
\hline
\end{tabular}

Hasil konsentrasi DNA sampel tertinggi dimiliki oleh sampel Tacapa Silver sebesar $1898 \mu \mathrm{g} / \mathrm{ml}$, sedangkan konsentrasi terendah dimiliki sampel Action 434 sebesar $655 \mu \mathrm{g} / \mathrm{ml}$, sampel Tacapa GB memiliki konsentrasi 1623 $\mu \mathrm{g} / \mathrm{ml}$ dan Aramis dengan konsentrasi 738 $\mu \mathrm{g} / \mathrm{ml}$.

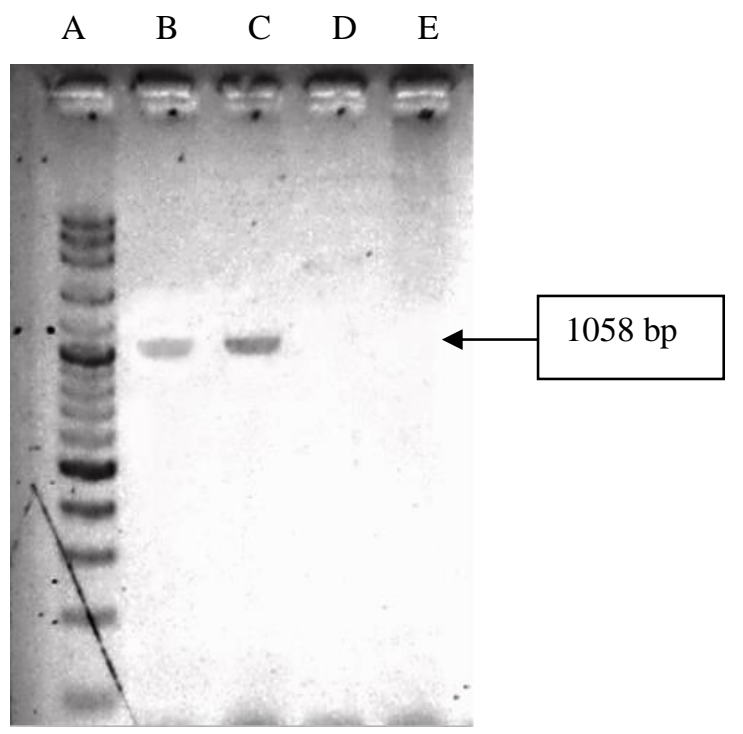

Gambar 1. Hasil elektroforesis dengan primer SCARs: A. Marker 100 bp; B. Tacapa GB; C. Tacapa Silver; D. Action 434; E. Aramis. 


\section{PEMBAHASAN}

Hasil Uji Kuantitatif dan Kualitatif DNA Hasil Isolasi. DNA, RNA dan protein memiliki nilai absorbansi sinar UV yang kuat pada rentang panjang gelombang $260 \mathrm{~nm}$ sampai $280 \mathrm{~nm}$. Sampel DNA dinyatakan murni jika nilai rasio absorbansi antara 1,7 sampai 1,9 dan 2 untuk RNA. Nilai rasio yang rendah atau dibawah 1,7 menunjukkan adanya kontaminasi protein, guanidine, fenol atau kontaminan lain yang memiliki nilai absorbansi yang tinggi pada panjang gelombang $280 \mathrm{~nm}$ (Fleige and Pfaffl, 2006; Li et al., 2002; Zhang et al., 2001). Pada umumnya nilai kemurnian DNA berbanding lurus dengan sensitivitas uji PCR, semakin tinggi kemurnian DNA maka sensitivitas PCR semakin meningkat (McOrist et al., 2002; Sagova-Mareckova et al., 2008). Berdasarkan pengujian yang dilakukan diketahui sampel DNA pada Tacapa GB, Tacapa Silver dan Action memiliki nilai rasio diatas 1,8 sedangkan sampel Aramis memiliki nilai rasio absorbansi rendah yaitu 1,648 (Tabel 1) meskipun demikian sampel yang diuji masih dapat digunakan untuk analisis selanjutnya.

Konsentrasi DNA digunakan sebagai acuan dalam proses pengenceran yang dilakukan saat amplifikasi. Konsentrasi DNA tertinggi dimiliki oleh sampel Tacapa Silver sebesar $1898 \mu \mathrm{g} / \mathrm{ml}$, sedangkan konsentrasi terendah dimiliki sampel Action 434 sebesar $655 \mu \mathrm{g} / \mathrm{ml}$ (Tabel 2). Menurut Huda dan Daryono (2013), konsentrasi paling baik yang dapat digunakan untuk PCR adalah sebanyak $70 \mu \mathrm{g} / \mathrm{ml}$. Uji kualitatif dilakukan untuk memastikan keberadaan molekul DNA dengan menggunakan gel elektroforesis.

\section{Hasil Analisis Molekuler dengan} Primer SCAR. Penanda SCAR yang digunakan dalam penelitian ini merupakan pengembangan dari primer RAPD penanda pUBC411 (Fukino et al., 2004) dengan menambahkan 15 nukleotida dari 10 nukleotida RAPD (Daryono et al., 2011). Primer SCAR digunakan dalam penelitian ini karena memiliki reproduktifitas yang tinggi dan bersifat lebih spesifik.

Amplifikasi DNA dilakukan dengan metode PCR. Tahap yang dilakukan adalah predenaturasi pada suhu $95^{\circ} \mathrm{C}$ selama 5 menit, denaturasi $95^{\circ} \mathrm{C}$ selama 1 menit, annealing $56^{\circ} \mathrm{C}$ selama 1 menit, elongasi $72^{\circ} \mathrm{C}$ selama 2 menit, dan post elongasi $72^{\circ} \mathrm{C}$ selama 10 menit. Untuk mendapatkan hasil yang optimum maka dilakukan optimasi pada suhu annealing, konsentrasi DNA, dan konsentrasi primer.

Sampel DNA yang telah diamplifikasi melalui proses PCR kemudian dipisahkan berdasarkan ukuran molekulnya dengan menggunakan metode elektroforesis. DNA hasil amplifikasi dipisahkan menggunakan gel agarose dengan konsentrasi 1,8\%. Pita-pita DNA yang terbentuk kemudian dilihat dibawah sinar UV dengan menggunakan UV trans-illuminator. Pita DNA yang menandakan gen ketahanan terhadap powdery mildew dapat teramati pada $1058 \mathrm{bp}$. Adanya pita DNA yang teramati pada 1058 bp menunjukkan bahwa kultivar melon tersebut memiliki gen ketahanan terhadap powdery mildew (Daryono et al., 2011).

Pengamatan hasil elektroforesis dibawah sinar UV menggunakan UV trans-illuminator (Gambar 1) menunjukkan tidak adanya gen ketahanan terhadap powdery mildew pada melon kultivar Aramis dan Action 434 dengan tidak munculnya pita DNA pada penanda 1058 bp. Sebaliknya munculnya pita DNA pada penanda 1058 bp menunjukkan adanya gen ketahanan terhadap powdery mildew pada Tacapa GB dan Tacapa Silver Gen yang dideteksi dengan penanda molekuler SCAR ini adalah gen $P m-W$. Gen tersebut ditemukan pada kultivar PI 371795, Tacapa, TP, dan hasil persilangan yang lain, akan tetapi tidak ditemukan pada kultivar Action 434 (Aristya dan Daryono, 2013).

\section{KESIMPULAN}

Melon Aramis tidak memiliki gen ketahanan terhadap powdery mildew.

\section{UCAPAN TERIMA KASIH}

Ucapan terimakasih kami sampaikan kepada Pusat Inovasi Agro Teknologi (PIAT UGM) yang telah memfasilitasi penelitian ini. Ucapan terimakasih juga kami sampaikan kepada KP3EI yang telah mendanai penelitian 
ini melalui hibah Masterplan Percepatan dan Perluasan Pembangunan Ekonomi Indonesia (MP3EI) tahun 2014.

\section{DAFTAR PUSTAKA}

Abood JK, amd Lösel DM. 2003. Changes in carbohydrate composition of cucumber leaves during the development of powdery mildew infection. Plant Pathology. vol 52(2): 256-265. https://doi.org/10.1046/j.13653059.2003.00814.x.

Aristya GR, dan Daryono BS. 2013. Deteksi dan Skrining Pewarisan Sifat Ketahanan Penyakit Powdery Mildew pada Generasi Backcross Tanaman Melon (Cucumis melo L.) Var. Tacapa [Tesis]. Yogyakarta: Universitas Gadjah Mada.

Atak A. 2017. Determination of downy mildew and powdery mildew resistance of some grape cultivars. South African Journal of Enology and Viticulture. vol 38(1): 11-17.

Daryono BS, Aristya GR, Kasiamdari RS. 2011. Development of random amplified polymorphism DNA markers linked to powdery mildew resistance gene ini melon. Indonesian Journal of Biotechnology. vol 16(2): 76-82.

Daryono BS, dan Qurrohman MT. 2009. Pewarisan Sifat Ketahanan Tanaman Melon (Cucumis melo L.) terhadap Powdery Mildew (Podosphaera xanthii (Castag.) Braun et Shishkoff). Jurnal Perlindungan Tanaman Indonesia. vol 15(1): $1-6$. https://doi.org/https://doi.org/10.22146/j pti.11758.

Fatmawati A, dan Daryono BS. 2016. Detection of Powdery Mildew (Podosphaera xanthii (Castagne) U. Braun \& N. Shishkoff) Resistance Gene in Melon (Cucumis melo L.) Cultivar Tacapa Green Black. Bioengineering and Bioscience. vol 4(4): 51-55.

Fleige S, and Pfaffl MW. 2006. RNA integrity and the effect on the real-time qRT-PCR performance. Molecular Aspects of Medicine. vol 27(2-3): 126-139. https://doi.org/10.1016/j.mam.2005.12.0
03.

Fukino N, Kunihisa M, Matsumoto M. 2004. Characterization of Recombinant Inbred Lines Derived from Crosses in Melon (Cucumis melo L.), 'PMAR No. 5' $\times$ 'Harukei No. 3.' Breeding Science. vol 54(2): 141-145. https://doi.org/https://doi.org/10.1270/jsb bs.54.141.

Gadoury DM, Seem RC, Pearson RC, Wilcox, WF, Dunst RM. 2001. Effects of Powdery Mildew on Vine Growth, Yield, and Quality of Concord Grapes. Plant Disease. vol 85(2): 137-140. https://doi.org/10.1094/PDIS.2001.85.2. 137.

Huda IN, dan Daryono BS. 2013. Analisis Variasi Genetik Melon (Cucumis melo L.) Kultivar Gama Melon Basket Dengan Metode Random Amplified Polymorphic DNA. Biogenesis: Jurnal Ilmiah Biologi, . vol 1(1): 41-50. https://doi.org/https://doi.org/10.24252/b io.v1i1.446.

Lebeda A, and Mieslerová B. 2011. Taxonomy, distribution and biology of lettuce powdery mildew (Golovinomyces cichoracearum sensu stricto). Plant Pathology. vol 60(3): 400-415. https://doi.org/10.1111/j.13653059.2010.02399.x.

Li S, Paulsson M, Björn LO. 2002. Temperature-dependent formation and photorepair of DNA damage induced by UV-B radiation in suspension-cultured tobacco cells. Journal of Photochemistry and Photobiology B: Biology. vol 66(1): 67-72. https://doi.org/10.1016/S10111344(01)00277-9.

Listiawan DA. 2009. Deteksi Gen Pengkode Sifat Ketahanan Terhadap Powdery Mildew (Podosphaera xanthii [Castagne] U. Braun \& N. Shishkoff) pada Melon (Cucumis melo L.) Dengan Penanda Molekuler Sequence Characterized Amplified Region (SCARs) [Skripsi]. Yogyakarta: Universitas Gadjah Mada.

McOrist AL, Jackson M, Bird AR. 2002. A comparison of five methods for extraction of bacterial DNA from human faecal 
samples. Journal of Microbiological Methods. vol 50(2): 131-139. https://doi.org/10.1016/S01677012(02)00018-0.

Pérez-García A, Romero D, FernÁndezOrtuÑo D, López-Ruiz F, De Vicente A, TorÉ, JA. 2009. The powdery mildew fungus Podosphaera fusca (synonym Podosphaera xanthii), a constant threat to cucurbits: Pathogen profile. Molecular Plant Pathology. vol 10(2): 153-160. https://doi.org/10.1111/j.13643703.2008.00527.x.

Kementerian Pertanian. 2015. Statistik Produksi Hortikultura Tahun 2014. Jakarta: Kementerian Pertanian Direktorat Jenderal Hortikultura.

Sagova-Mareckova M, Cermak L, Novotna J, Plhackova K, Forstova J, Kopecky J. 2008. Innovative methods for soil DNA purification tested in soils with widely differing characteristics. Applied and
Environmental Microbiology. vol 74(9): 2902-2907. https://doi.org/10.1007/9783-540-85754-9_8.

Stummer BE, Francis IL, Zanker T, Lattey K A, Scott ES. 2005. Effects of powdery mildew on the sensory properties and composition of Chardonnay juice and wine when grape sugar ripeness is standardised. Australian Journal of Grape and Wine Research. vol 11(1): 6676. $\quad$ https://doi.org/10.1111/j.17550238.2005.tb00280.x.

Zhang QL, Liu JG, Chao H, Xue GQ, Ji LN. 2001. DNA-binding and photocleavage studies of cobalt(III) polypyridyl complexes: $\quad[\mathrm{Co}($ phen $) 2 \mathrm{IP}] 3+\quad$ and $[\mathrm{Co}($ phen)2PIP $] 3+$. Journal of Inorganic Biochemistry. vol 83(1): 49-55. https://doi.org/https://doi.org/10.1016/S0 162-0134(00)00132-X. 